\title{
Changes in flipper beat frequency, body angle and swimming speed of female green turtles Chelonia mydas
}

\author{
Tohya Yasuda ${ }^{1,2, *}$, Nobuaki Arai ${ }^{1}$ \\ ${ }^{1}$ Department of Social Informatics, Graduate school of Informatics, Kyoto University, Yoshidahonmachi, \\ Sakyo-ku, Kyoto 606-8501, Japan \\ ${ }^{2}$ Present address: School of Agriculture, Kinki University, Nakamachi 3327-204, Nara 631-8505, Japan
}

\begin{abstract}
Data loggers were utilized to record depth, temperature, biaxial motion and swimming speed for female green turtles Chelonia mydas between nesting events in Thailand. The present study demonstrated clear alternations in swimming effort with depth. Both resident and maximum dive depths significantly affected flipper beat frequency, suggesting that turtles change flipper beat frequency with current buoyancy in ways similar to other diving mammals and birds. Body angles became steepest during the initial phases of descent and ascent, but were $<60^{\circ}$. Swimming speeds were related to flipper beat frequency and current buoyancy. Swimming speeds based on the dominant stroke frequency during the inter-nesting period $(0.18$ to $0.21 \mathrm{~Hz})$ were estimated at 0.52 to 0.60 curved carapace lengths $\mathrm{s}^{-1}$. These values are similar to the modal speeds of the leatherback turtles Dermochelys coriacea and the mean speeds during the initial descent of the loggerhead turtles Caretta caretta. We calculated the dynamic body acceleration (DBA) as the index of activity during the descent and ascent phases and found a relationship between maximum dive depth and DBA. Although active stroking during deeper dives may result in a shorter dive duration, daytime dives (ca. 16 to $26 \mathrm{~m}$ ) were deeper than those observed during the night (ca. 9 to $13 \mathrm{~m}$ ). This result suggests a beneficial reproductive strategy for females that involves changes in vertical space, for example, to obtain refuge from energy-consuming encounters with males or predators.
\end{abstract}

KEY WORDS: Diving behaviour $\cdot$ Chelonia mydas $\cdot$ Sea turtles $\cdot$ Flipper beat frequency $\cdot$ Swimming speed $\cdot$ Body angle

Resale or republication not permitted without written consent of the publisher

\section{INTRODUCTION}

As air-breathing vertebrates descend during a dive, the buoyancy varies due to the compression of gas in the lungs and/or the plumage (for birds), in accordance with Boyle's law. Such changes in buoyancy may aid or impede swimming efficiency (Wilson et al. 1992). In this situation, some deep-diving mammals exhale prior to submergence. Alternatively, they use oxygen in their blood and tissues during the dive (Butler \& Jones 1997). The costs of swimming for these animals are also affected by drag forces, which increase exponentially with swimming speed (Schmidt-Nielsen 1984, Williams et al. 1993). Therefore, these diving vertebrates are likely to tactically use both an active stroke swimming and passive glide swimming, as the situation demands (e.g. Williams et al. 2000, Sato et al. 2003, Watanuki et al. 2003). In fact, a narrow range of swimming speeds during a dive (Williams et al. 1993, Boyd et al. 1995) and the decline in thrust or stroke frequency have been demonstrated to parallel changes in buoyancy with depth (Lovvorn et al. 1999, Watanuki et al. 2003, 2005).

To date, few studies have investigated the swimming effort of hard-shelled sea turtles during a dive compared to those of diving mammals and birds. Hays et al. (2007) examined the flipper beat frequency and amplitude of green turtles Chelonia mydas using an animal-borne video camera (CRITTERCAM; Marshall 1998) and found that these parameters decreased as the descent or ascent continued, suggesting that a gen- 
eral rule applies across a diverse range of mammalian, avian and reptilian divers. Similar flipper beat frequencies were recorded for a single green turtle equipped with an IMASEN data logger (Hays et al. 2004a). However, there is no empirical evidence of changes in swimming effort in relation to instantaneous (i.e. resident) depth or maximum dive depth. In addition, the diving behaviour of gravid female turtles differs from that of these animals in at least one fundamental respect: female sea turtles of a number of species, including green turtles, loggerhead turtles Caretta caretta and hawksbill turtles Eretmochelys imbricata, which have a low metabolic rate compared to other non-reptilian diving animals (e.g. Hays 2008), may fast during the nesting period (Limpus \& Reed 1985, Starbird et al. 1999, Hays et al. 2002, T. Yasuda unpubl. data), with the exception of some populations (e.g. Hochscheid et al. 1999). Alternatively, they spend much of the inter-nesting periods on the seabed or at a distinct depth performing U-shaped (Hochscheid et al. 1999, Hays et al. 2000, Houghton et al. 2002, 2008) or S-shaped (Minamikawa et al. 2000; also see Hochscheid et al. 1999) resting dives to conserve energy for reproduction. It is expected that the most efficient depth is the shallowest depth at which the turtle is allowed to establish neutral buoyancy. If turtles dive considerably deeper than the depth at which neutral buoyancy is attained, travelling costs may decrease the resting duration. Therefore, selecting the depth at which turtles attain close to neutral buoyancy, in accordance with pre-submergence inspiration, may be important for conserving energy for reproduction (Minamikawa et al. 1997, 2000, Hays et al. 2004b).

In the present study, to bridge the gap in our understanding of swimming effort between sea turtles and other non-reptilian diving animals, we deployed acceleration data loggers to record stroke frequency, body angle, swimming speed and ambient water temperature for gravid female green turtles. The aim of the present study was to determine if flipper beat frequency, body angle and swimming speed are regulated by both the resident and maximum dive depths and to examine the relationship between dive depth and dive duration using an index of activity level calculated based on accelerations.

\section{MATERIALS AND METHODS}

Study site, field survey and instrument deployment. Field surveys were conducted in 2006 at Huyong Island ( $\left.8^{\circ} 29^{\prime} \mathrm{N}, 97^{\circ} 38^{\prime} \mathrm{E}\right)$, Thailand. Huyong Island is a small oceanic remote island (area: $1.62 \mathrm{~km}^{2}$ ) that has a sandy beach for year-round nesting populations of green turtles Chelonia mydas (Yasuda et al. 2006).
Nesting females were found by night patrols on the beach. The instrument was attached and curved carapace length (CCL) was measured after nesting. Two types of accelerometers were used separately (i.e. W380L-PD2GT and UME190L-D2GT; Little Leonard Ltd.), with 12-bit resolution, to obtain the depth, ambient temperature, biaxial acceleration and swimming speed of turtles. The D2GT and PD2GT were 15 and $27 \mathrm{~mm}$ in diameter and 53 and $128 \mathrm{~mm}$ in length and had masses of 16 and $73 \mathrm{~g}$ in the air, respectively. The full recording range depth was $380 \mathrm{~m}$, with a resolution of $0.093 \mathrm{~m}$ for PD2GT, and $190 \mathrm{~m}$, with a resolution of $0.046 \mathrm{~m}$ for D2GT. The measuring ranges were $\pm 49 \mathrm{~m} \mathrm{~s}^{-2}$, with a resolution of $0.02 \mathrm{~m} \mathrm{~s}^{-2}$ for acceleration, and -20 to $50^{\circ} \mathrm{C}$, with a resolution of $0.018^{\circ} \mathrm{C}$ for temperature. We measured the surge acceleration along the long axis of the body and the heave acceleration along the orthogonal axis of the surge acceleration. Swimming speed was only obtained by PD2GT. The swimming speed was converted from the rotation of an external propeller by a calibration experiment using a water circulation tank. The rotation of the propeller was unstable at water flow speeds of $<0.2 \mathrm{~m} \mathrm{~s}^{-1}$. However, at water flow speeds of $>0.2 \mathrm{~m} \mathrm{~s}^{-1}$, linear relationships between the rotation number of the propeller and water flow speed were obtained with a high coefficient of determination that was $>0.9$ for all data loggers. This enabled us to compare the swimming speeds of the green turtles. Sampling intervals were $1 \mathrm{~Hz}$ for depth and swimming speed, $0.1 \mathrm{~Hz}$ for temperature and $16 \mathrm{~Hz}$ for acceleration. The data logger was attached to the top of the carapace using a quick-setting epoxy resin (Quick-5, Konishi Ltd.) in accordance with the Japan Ethological Society guidelines for the experimental use of animals. Total attachment durations were $<30 \mathrm{~min}$. Turtles with instruments returned to the same beach approximately $12 \mathrm{~d}$ later for the next nesting, and data loggers were retrieved from the turtles after the subsequent nestings were completed.

Diving behaviour. Recently, accelerometers have been utilized to analyse the locomotion of both terrestrial and aquatic animals (Yoda et al. 2001, Watanabe et al. 2005, Tsuda et al. 2006, Wilson et al. 2006). The accelerometers can measure both dynamic acceleration (e.g. propulsive activities) and static acceleration (e.g. gravity). High-frequency components of the surge acceleration were used to calculate the flipper beating of the turtles. In contrast, low-frequency components of the longitudinal acceleration along the long axis of the body were used to calculate the pitch angle of the turtles (see Sato et al. 2003). The low-frequency component of the acceleration was obtained using an Igor Filter Design Laboratory (IFDL) Version 2.0 (WaveMetrics), which removed the high-frequency component based on flipper strokes measured by the $0.1 \mathrm{~Hz}$ low-pass filter. 
The diving behaviour of the turtles was divided into 6 different dive types. A generalized time-series of the depth profile has been published by Seminoff et al. (2006). In the present study, we focused on the flat-bottom U-shaped dive (Type 1), which is the dive most commonly performed by female green turtles during the inter-nesting period (Hochscheid et al. 1999, Hays et al. 2000, 2004b). Dive data were automatically analysed using a macro in Igor Pro Version 5.0 (WaveMetrics). A dive was defined as a depth of $>3 \mathrm{~m}$ for at least $30 \mathrm{~s}$ to extract dive parameters for each dive.

We detected all individual flipper movements during each dive. Flipper movements were defined as highfrequency components of acceleration $>0.01 \mathrm{~m} \mathrm{~s}^{-2}$ for at least $1 \mathrm{~s}$. We defined the time of the flipper beat as the time of maximum acceleration during each flipper movement. Using the intervals between consecutive flipper beats, we then calculated the instantaneous flipper beat frequency. The U-shaped resting dive was defined as the turtle remaining within $50 \mathrm{~cm}$ of the maximum depth for $>80 \%$ of the dive duration to account for the resolution of the loggers. The start and end of the bottom phase were defined as those times associated with successive flipper beats, which had the longest flipper beat frequency, since both landing and take-off from the seabed were accompanied by flipper beats. The maximum dive depth was defined as the maximum depth during the bottom phase. Visual analysis of individual dive profiles and statistical values obtained for each parameter confirmed that the macro successfully captured the dives and each parameter. If these items were not successfully captured by the macro, they were corrected manually.

Dominant stoke cycle frequency during the monitoring period. To determine the dominant stroke cycle frequency of the turtles from the time-series data, the periodic properties of the acceleration signal were analysed. Power spectral density (PSD) was calculated from the high-frequency component of the entire surge acceleration dataset for each turtle using a fast Fourier transform (FFT) with a computer programme package in Igor. The dominant stroke cycle frequency was defined as the value obtained at the peak power spectral density for each turtle. Diving mammals and birds employ both active stroke swimming and passive glide swimming, according to the situation. As an index of the depth at which turtles begin to conduct passive glide swimming, the instantaneous depth when flipper beat frequency was below the dominant stroke cycle frequency (hereafter, the instantaneous depth is termed DFBD) was calculated. To determine the beginning of the glide swimming, $0.18 \mathrm{~Hz}$, which was the lowest value associated with each turtle, was used as the dominant stroke cycle frequency (Table 1). If the flipper beat frequency of a turtle was continuously above the dominant stroke cycle frequency throughout the descent and ascent phases, the DFBD was considered to be the maximum dive depth.

Dynamic body acceleration (DBA). Recent studies suggest that acceleration can serve as a proxy for the rate of energy expenditure in free-living animals (Wilson et al. 2006, Halsey et al. 2008, Green et al. 2009). In the present study, we calculated the DBA as the index of activity during the descent and ascent phases. Highfrequency components of the surge and heave accelerations were converted into absolute positive units, and the resulting values from both channels were added to obtain an overall value for the biaxial acceleration. We summed the total amount of DBA for the whole of the descent or ascent phase in any single dive. These values were used in regressions of DBA versus the maximum dive depth for turtles.

Statistical analyses. To examine whether both resident and dive depths affect flipper beat frequency, body angle and swimming speed, we applied the generalized linear mixed model (GLMM; Schall 1991) with restricted maximum likelihood (REML) analysis. The mixed model allows both fixed and random terms to be fitted, while random terms take into consideration repeated sampling. The resident and maximum dive depths were defined as the fixed effects, and an interaction between these variables was also considered. We fitted the identity of individuals as the random effect and ran separate statistical analyses on the descent and ascent phases. Before application of the model, we calculated the mean values of the flipper beat frequency, body angle and swimming speed at depths ranging from 0 to 5,5 to 10,10 to $15 \mathrm{~m}$, etc.,

Table 1. Chelonia mydas. Summary of the diving data for female green turtles during the inter-nesting period at Huyong Island, Thailand, in 2006. CCL: curved carapace length

\begin{tabular}{|ccccccrrr|}
\hline Turtle & Loggers & $\begin{array}{c}\text { Recording } \\
\text { period }\end{array}$ & $\begin{array}{c}\text { Dive depth } \\
(\mathrm{m})\end{array}$ & $\begin{array}{c}\text { Dive duration } \\
(\mathrm{min})\end{array}$ & $\begin{array}{c}\text { Dominant stroke } \\
\text { cycle frequency (Hz) }\end{array}$ & $\begin{array}{c}\text { CCL } \\
\text { (cm) }\end{array}$ & $\begin{array}{c}\text { No. of } \\
\text { U-dives }\end{array}$ & $\begin{array}{c}\text { Total no. } \\
\text { of dives }\end{array}$ \\
\hline CM1 & PD2GT & 6-11 Mar & $13.21 \pm 5.75$ & $45.01 \pm 8.33$ & 0.19 & 99 & 93 \\
CM2 & PD2GT & 9-15 Mar & $10.10 \pm 4.37$ & $38.31 \pm 15.23$ & 0.18 & 90 & 132 & 348 \\
CM3 & D2GT & 14-17 Mar & $23.62 \pm 7.42$ & $58.27 \pm 12.73$ & 0.18 & 103 & 65 & 137 \\
CM4 & D2GT & 14-18 Mar & $14.48 \pm 13.38$ & $29.61 \pm 10.04$ & 0.21 & 101 & 58 \\
\hline
\end{tabular}


for each individual. Statistical analyses were performed using SPSS Version $15.0 \mathrm{~J}$ for Windows (SPSS). We included all likely independent terms and possible interactions in the maximal model and excluded terms sequentially until the model included only those terms whose elimination would significantly decrease the Akaike's information criterion (AIC) of the model.

\section{RESULTS}

\section{Diving behaviour}

A total of 348 (58 to 132) U-shaped dives was obtained from 4 female green turtles Chelonia mydas during the inter-nesting periods (Table 1). The mean bottom depth at which the turtles rested on the seabed ranged from $13.21 \pm 5.75 \mathrm{~m}(\mathrm{n}=93$ dives $)$ to $23.62 \pm 7.42 \mathrm{~m}(\mathrm{n}=65$ dives $)$. Mean dive duration ranged from $29.61 \pm 10.04 \mathrm{~min}(\mathrm{n}=41$ dives $)$ to $58.27 \pm 12.73 \mathrm{~min}(\mathrm{n}=65$ dives$)$. Although the flatbottom dives were observed during both the day and at night, there was a significant difference in maximum dive depth between daytime and nighttime over the recording period (Fig. 1, Table 2). In contrast, no apparent pattern was detected between daytime and nighttime dive durations (Table 2). Dive duration was affected by the bottom depth (Fig. 2), and the relationships between these variables for each turtle were typically explained by a quadratic curve (Table 3).

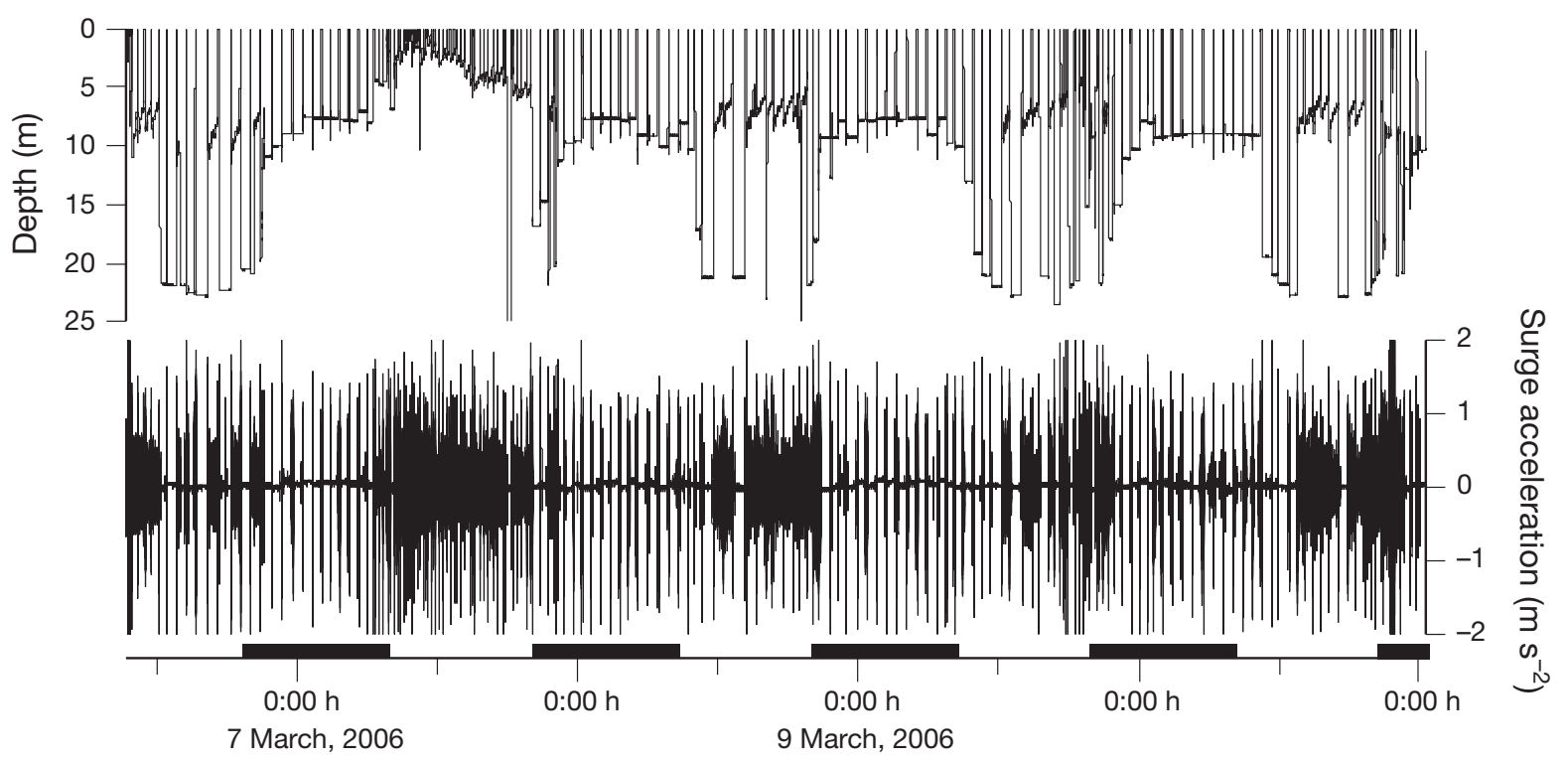

Fig. 1. Chelonia mydas. An example (Turtle CM1) of diel alternations in the maximum dive depth and high-frequency component of surging acceleration during the inter-nesting period for female green turtles, nested at Huyong Island, Thailand. Black bars indicate nighttime (19:00 to 06:59 h)

Table 2. Chelonia mydas. Results of Student's $t$-test and Wilcoxon test for comparison between day ( $\mathrm{D} ; 07: 00$ to 18:59 h) and night $\left(\mathrm{N}_{i}\right.$ 19:00 to $\left.06: 59 \mathrm{~h}\right)$ in the diving parameters

\begin{tabular}{|c|c|c|c|c|c|c|c|}
\hline Turtle & Parameters & $\begin{array}{c}\text { Day } \\
(\text { mean } \pm \mathrm{SD})\end{array}$ & $\begin{array}{c}\text { Night } \\
(\text { mean } \pm \text { SD) }\end{array}$ & $\begin{array}{c}\mathrm{n} \\
(\mathrm{D} \text { vs. N)}\end{array}$ & $t$ or $\chi^{2}$ & df & $\mathrm{p}$ \\
\hline CM1 & $\begin{array}{l}\text { Resident depth (m) } \\
\text { Dive depth }(\mathrm{m}) \\
\text { Duration (min) }\end{array}$ & $\begin{array}{l}10.36 \pm 7.65 \\
16.89 \pm 5.92 \\
47.27 \pm 8.10\end{array}$ & $\begin{array}{r}9.45 \pm 4.75 \\
10.43 \pm 3.76 \\
43.30 \pm 8.17\end{array}$ & $\begin{array}{c}255600 \text { vs. } 220226 \text { (point) } \\
40 \text { vs. } 53 \text { (dive) } \\
40 \text { vs. } 53\end{array}$ & $\begin{array}{c}47.91 \\
25.215 \\
4.118\end{array}$ & $\begin{array}{c}475824 \\
1 \\
1\end{array}$ & $\begin{array}{r}<0.001 \\
<0.001 \\
0.0424\end{array}$ \\
\hline CM2 & $\begin{array}{c}\text { Resident depth (m) } \\
\text { Depth (m) } \\
\text { Duration (min) }\end{array}$ & $\begin{array}{l}20.57 \pm 9.00 \\
22.45 \pm 7.23 \\
46.16 \pm 17.58\end{array}$ & $\begin{array}{r}8.15 \pm 3.00 \\
9.23 \pm 2.09 \\
32.13 \pm 9.31\end{array}$ & $\begin{array}{c}256800 \text { vs. } 223875 \\
58 \text { vs. } 74 \\
58 \text { vs. } 74\end{array}$ & $\begin{array}{l}623.487 \\
88.961 \\
28.112\end{array}$ & $\begin{array}{c}480673 \\
1 \\
1\end{array}$ & $\begin{array}{l}<0.001 \\
<0.001 \\
<0.001\end{array}$ \\
\hline CM3 & $\begin{array}{c}\text { Resident depth (m) } \\
\text { Depth (m) } \\
\text { Duration (min) }\end{array}$ & $\begin{array}{l}21.43 \pm 10.47 \\
26.31 \pm 7.91 \\
58.55 \pm 12.01\end{array}$ & $\begin{array}{l}19.80 \pm 8.13 \\
20.49 \pm 5.40 \\
57.91 \pm 13.7\end{array}$ & $\begin{array}{c}172800 \text { vs. } 155986 \\
35 \text { vs. } 30 \\
35 \text { vs. } 30\end{array}$ & $\begin{array}{c}49.255 \\
7.821 \\
0.014\end{array}$ & $\begin{array}{c}328784 \\
1 \\
1\end{array}$ & $\begin{array}{r}<0.001 \\
0.0052 \\
0.9057\end{array}$ \\
\hline $\mathrm{CM} 4$ & $\begin{array}{c}\text { Resident depth (m) } \\
\text { Depth (m) } \\
\text { Duration (min) }\end{array}$ & $\begin{array}{l}11.50 \pm 12.26 \\
16.43 \pm 20.16 \\
23.10 \pm 10.37\end{array}$ & $\begin{array}{r}9.99 \pm 8.20 \\
13.29 \pm 6.62 \\
33.57 \pm 7.53\end{array}$ & $\begin{array}{c}172800 \text { vs. } 180959 \\
22 \text { vs. } 36 \\
22 \text { vs. } 36\end{array}$ & $\begin{array}{c}43.075 \\
6.33 \\
16.7\end{array}$ & $\begin{array}{c}353757 \\
1 \\
1\end{array}$ & $\begin{array}{c}<0.001 \\
0.0121 \\
<0.001\end{array}$ \\
\hline
\end{tabular}




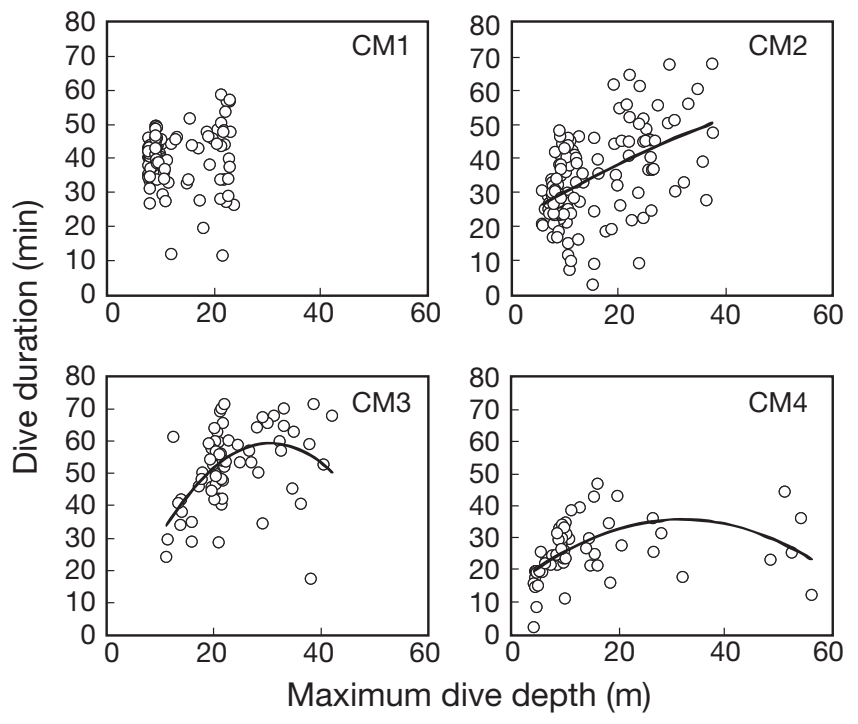

Fig. 2. Chelonia mydas. Relationships between maximum dive depth and dive duration during the inter-nesting period for 4 female green turtles nested at Huyong Island, Thailand. Bottom depth is the maximum dive depth of a U-shaped dive. A regression curve is shown in each graph for significant relationships. Statistical analysis is described in Table 3

\section{Behaviour during descent}

A distinct alternation in flipper beat frequency, body angle, and swimming speed was observed during a Ushaped dive (Fig. 3). At the initial phase of descent, a high frequency of flipper beating at 0.3 to $0.6 \mathrm{~Hz}$ was observed (Fig. 4A). The flipper beat frequency during deep dives was higher than that during shallow dives (Fig. 4), such that the bottom depth of a dive significantly affected the flipper beat frequency (Table 4). There was a significant effect of resident depth on flipper beat frequency (Fig. 4A, Table 4). However, the decline in flipper beat frequency stopped at 0.1 to $0.2 \mathrm{~Hz}$, when turtles reached a depth of 15 to $20 \mathrm{~m}$, and the flipper beat frequency was approximately constant despite changes in depth. The depth at which the frequency of flipper beating significantly decreased (i.e. DFBD) was affected by the bottom depth (Fig. 5), and the relationship between the bottom depth and DFBD could be described by a logistic curve (Table 3).

No vertical body angles of the turtles were observed, but the angles were steepest (approximately $-60^{\circ}$ ) at depths of 5 to $10 \mathrm{~m}$ (Fig. 4B). Subsequently, the body angles became significantly shallower as turtles descended the water column, although body angles were generally steeper during deeper dives (Table 4, Fig. 4B).

Swimming speeds were highest at the start of the descent (Figs. $3 \& 4 \mathrm{C}$ ), and varied in an alternating fashion in accordance with the flipper beating during
Table 3. Chelonia mydas. Results from regression analysis of the dive parameters during the inter-nesting period for green turtles nested at Huyong Island, Thailand. DFBD: instantaneous depth when flipper beat frequency was below the dominant stroke cycle frequency; DBA: sum of the total amount of dynamic body acceleration for the whole of the descent or ascent phase in any single dive; ns: not significant

\begin{tabular}{|c|c|c|c|}
\hline & $y=$ & $r^{2}$ & $\mathrm{p}$ \\
\hline \multicolumn{4}{|c|}{ CM1 $(\mathrm{n}=93$, max. depth range $=7.6$ to $23.6 \mathrm{~m})$} \\
\hline $\begin{array}{l}\text { DFBD descent (m) vs. } \\
\text { max. dive depth }(\mathrm{m})\end{array}$ & $-0.2+3.4 \ln (x)$ & 0.51 & $<0.0001$ \\
\hline $\begin{array}{l}\text { DFBD ascent (m) vs. } \\
\text { max. dive depth (m) }\end{array}$ & $2.6+\ln (x)$ & 0.16 & $<0.0001$ \\
\hline $\begin{array}{l}\text { Dive duration (min) vs. } \\
\text { max. dive depth }(\mathrm{m})\end{array}$ & ns & ns & ns \\
\hline $\begin{array}{l}\text { Dive duration }(\min ) \text { vs. } \\
\text { mean temp. }\left({ }^{\circ} \mathrm{C}\right)\end{array}$ & ns & ns & ns \\
\hline $\begin{array}{l}\text { DBA during descent vs. } \\
\text { max. dive depth }(\mathrm{m})\end{array}$ & ns & ns & ns \\
\hline $\begin{array}{l}\text { DBA during descent vs. } \\
\text { max. dive depth }(\mathrm{m})\end{array}$ & $-8.5+6.0 x$ & 0.49 & $<0.0001$ \\
\hline \multicolumn{4}{|c|}{ CM2 $(\mathrm{n}=132$, max. depth range $=5.8$ to $37.2 \mathrm{~m})$} \\
\hline $\begin{array}{l}\text { DFBD descent (m) vs. } \\
\text { max. dive depth }(\mathrm{m})\end{array}$ & $-9.4+7.6 \ln (x)$ & 0.77 & $<0.0001$ \\
\hline $\begin{array}{l}\text { DFBD ascent (m) vs. } \\
\text { max. dive depth }(\mathrm{m})\end{array}$ & $-7.5+5.1 \ln (x)$ & 0.66 & $<0.0001$ \\
\hline $\begin{array}{l}\text { Dive duration (min) vs. } \\
\text { max. dive depth }(\mathrm{m})\end{array}$ & $20.8+x-0.005 x^{2}$ & 0.25 & $<0.0001$ \\
\hline $\begin{array}{l}\text { Dive duration }(\min ) \text { vs. } \\
\text { mean temp. }\left({ }^{\circ} \mathrm{C}\right)\end{array}$ & ns & ns & $\mathrm{ns}$ \\
\hline $\begin{array}{l}\text { DBA during descent vs. } \\
\text { max. dive depth }(\mathrm{m})\end{array}$ & $42.2+3.9 x$ & 0.11 & $<0.0001$ \\
\hline $\begin{array}{l}\text { DBA during descent vs. } \\
\text { max. dive depth }(\mathrm{m})\end{array}$ & $14.5+2.7 x$ & 0.48 & $<0.0001$ \\
\hline \multicolumn{4}{|c|}{ CM3 $(n=65$, max. depth range $=11.2$ to $42.1 \mathrm{~m})$} \\
\hline $\begin{array}{l}\text { DFBD descent }(\mathrm{m}) \text { vs. } \\
\text { max. dive depth }(\mathrm{m})\end{array}$ & $-12.7+9.2 \ln (x)$ & 0.61 & $<0.0001$ \\
\hline $\begin{array}{l}\text { DFBD ascent (m) vs. } \\
\text { max. dive depth (m) }\end{array}$ & $-10+6.7 \ln (x)$ & 0.51 & $<0.0001$ \\
\hline $\begin{array}{l}\text { Dive duration (min) vs. } \\
\text { max. dive depth (m) }\end{array}$ & $\begin{array}{c}-3.7+ \\
4.1 x-0.1 x^{2}\end{array}$ & 0.23 & 0.0002 \\
\hline $\begin{array}{l}\text { Dive duration }(\min ) \text { vs. } \\
\text { mean temp. }\left({ }^{\circ} \mathrm{C}\right)\end{array}$ & $\begin{array}{c}-2629.9+ \\
191.9 x-3.4 x^{2}\end{array}$ & 0.1 & 0.0380 \\
\hline $\begin{array}{l}\text { DBA during descent vs. } \\
\text { max. dive depth }(\mathrm{m})\end{array}$ & $338.7-7.6 x$ & 0.2 & 0.0003 \\
\hline $\begin{array}{l}\text { DBA during descent vs. } \\
\text { max. dive depth }(\mathrm{m})\end{array}$ & $1.6+2.6 x$ & 0.57 & $<0.0001$ \\
\hline \multicolumn{4}{|c|}{ CM4 $(\mathrm{n}=58$, max. depth range $=3.8$ to $54.2 \mathrm{~m})$} \\
\hline $\begin{array}{l}\text { DFBD descent }(\mathrm{m}) \text { vs. } \\
\text { max. dive depth }(\mathrm{m})\end{array}$ & $-6.9+6.3 \ln (x)$ & 0.87 & $<0.0001$ \\
\hline $\begin{array}{l}\text { DFBD ascent (m) vs. } \\
\text { max. dive depth (m) }\end{array}$ & $-9.5+5.8 \ln (x)$ & 0.81 & $<0.0001$ \\
\hline $\begin{array}{l}\text { Dive duration (min) vs. } \\
\text { max. dive depth }(\mathrm{m})\end{array}$ & $\begin{array}{c}-14.8+ \\
1.3 x-0.02 x^{2}\end{array}$ & 0.23 & 0.0005 \\
\hline $\begin{array}{l}\text { Dive duration }(\min ) \\
\text { mean temp. }\left({ }^{\circ} \mathrm{C}\right)\end{array}$ & $\begin{array}{c}-983.9+ \\
75.9 x-1.4 x^{2}\end{array}$ & 0.17 & 0.0057 \\
\hline $\begin{array}{l}\text { DBA during descent vs. } \\
\text { max. dive depth }(\mathrm{m})\end{array}$ & $51.8+3.6 x$ & 0.27 & $<0.0001$ \\
\hline $\begin{array}{l}\text { DBA during descent vs. } \\
\text { max. dive depth }(\mathrm{m})\end{array}$ & $9.5+2.8 x$ & 0.79 & $<0.0001$ \\
\hline
\end{tabular}




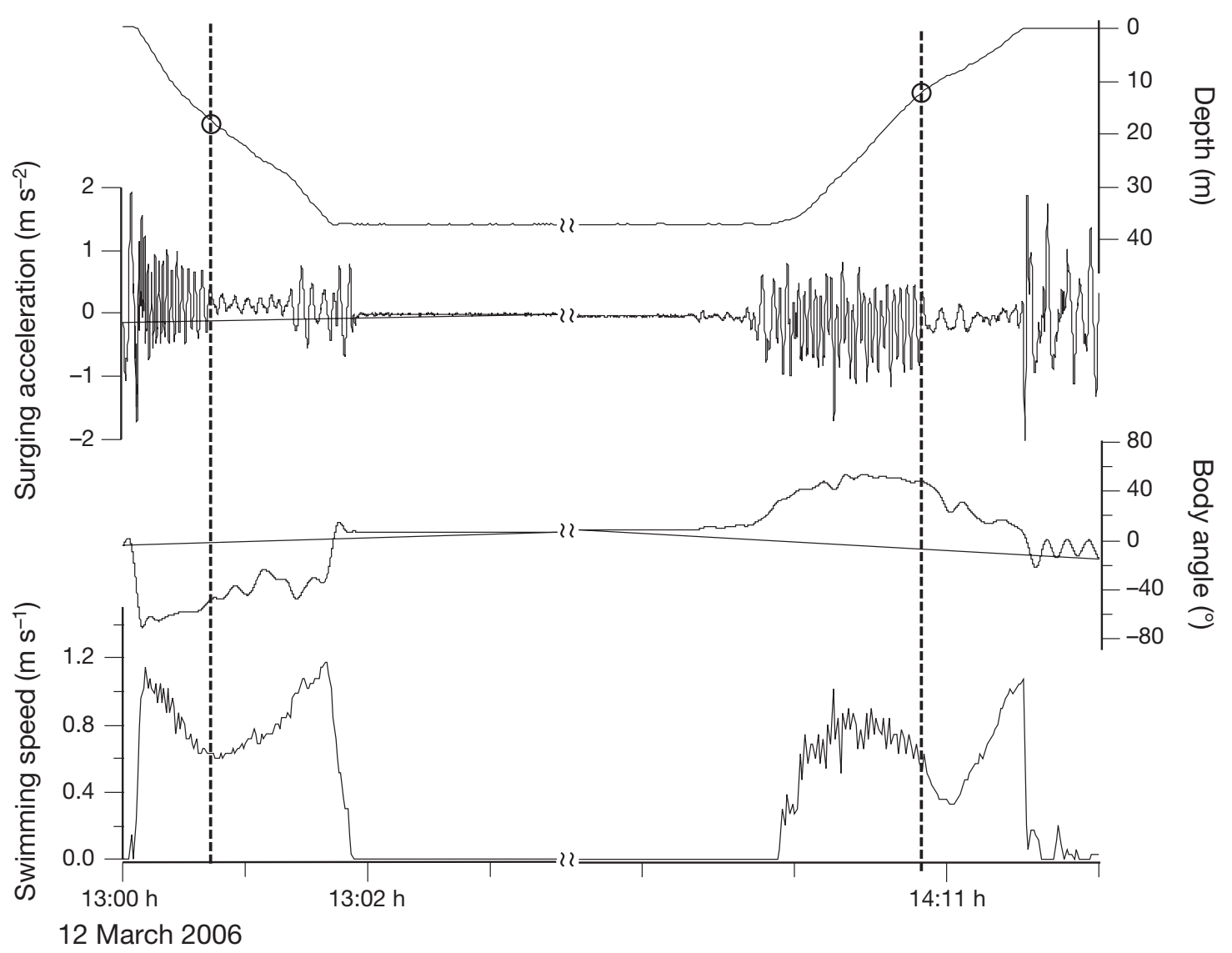

Fig. 3. Chelonia mydas. Time-series of depth, high-frequency components of surging acceleration, body angle and swimming speed during a U-shaped dive of a female green turtle (CM2), during the inter-nesting period at Huyong Island, Thailand. O: Depth where the flipper beat frequency was below the dominant stroke cycle frequency (DFBD); dashed vertical lines: DFBD time. Note that the bottom phase is omitted in this figure, since the diving parameters rarely varied during the bottom phase in the U-shaped dive, when the green turtles typically rested on the seabed

the initial phase (Fig. 3). The swimming speeds and flipper beat frequency decreased as depth increased (Fig. 4C). There was also a significant effect of flipper beat frequency on swimming speed (Fig. 6). When the turtles reached depths of 15 to $20 \mathrm{~m}$, the decline in swimming speeds halted at 0.6 to $0.8 \mathrm{~m} \mathrm{~s}^{-1}$. However, swimming speeds subsequently increased despite less flipper stroking (Figs. $3 \& 4$ A, C).

Relationships between maximum dive depth and DBA were detected during the descent phase for only 3 individuals, but the correlation coefficients $\left(\mathrm{r}^{2}\right)$ were low (Fig. 7, Table 3).

\section{Behaviour during ascent}

The pattern of changes in flipper beat frequency, body angle and swimming speed during the ascent was generally similar to that during the descent (Figs. $3 \& 4$ ). Thus, there were also significant effects of current and bottom depth on these parameters (Table 4). However, turtles did not beat their flippers strongly at the end of the ascent, as they did at the end of the descent (Fig. 3). The maximum dive depth also significantly affected DFBD, but this depth was shallower than during the descent (paired $t$-test, $\mathrm{p}<0.05$; Fig. 5). Maximum dive depth significantly affected DBA during the ascent phase (Fig. 7, Table 3).

\section{Behaviour and temperature in the bottom phase}

Dynamic acceleration indicated that turtles rested during the bottom phase in the analysed U-shaped dives (Figs. $1 \& 3$ ). Mean ambient water temperature during the bottom phase ranged from $28.23 \pm 1.54^{\circ} \mathrm{C}$ ( $\mathrm{n}=93$ dives) to $29.31 \pm 0.69^{\circ} \mathrm{C}(\mathrm{n}=132$ dives). Relationships existed between ambient water temperature and dive duration for only 2 individuals, but the correlation coefficients $\left(\mathrm{r}^{2}\right)$ were very low (Table 3 ). 

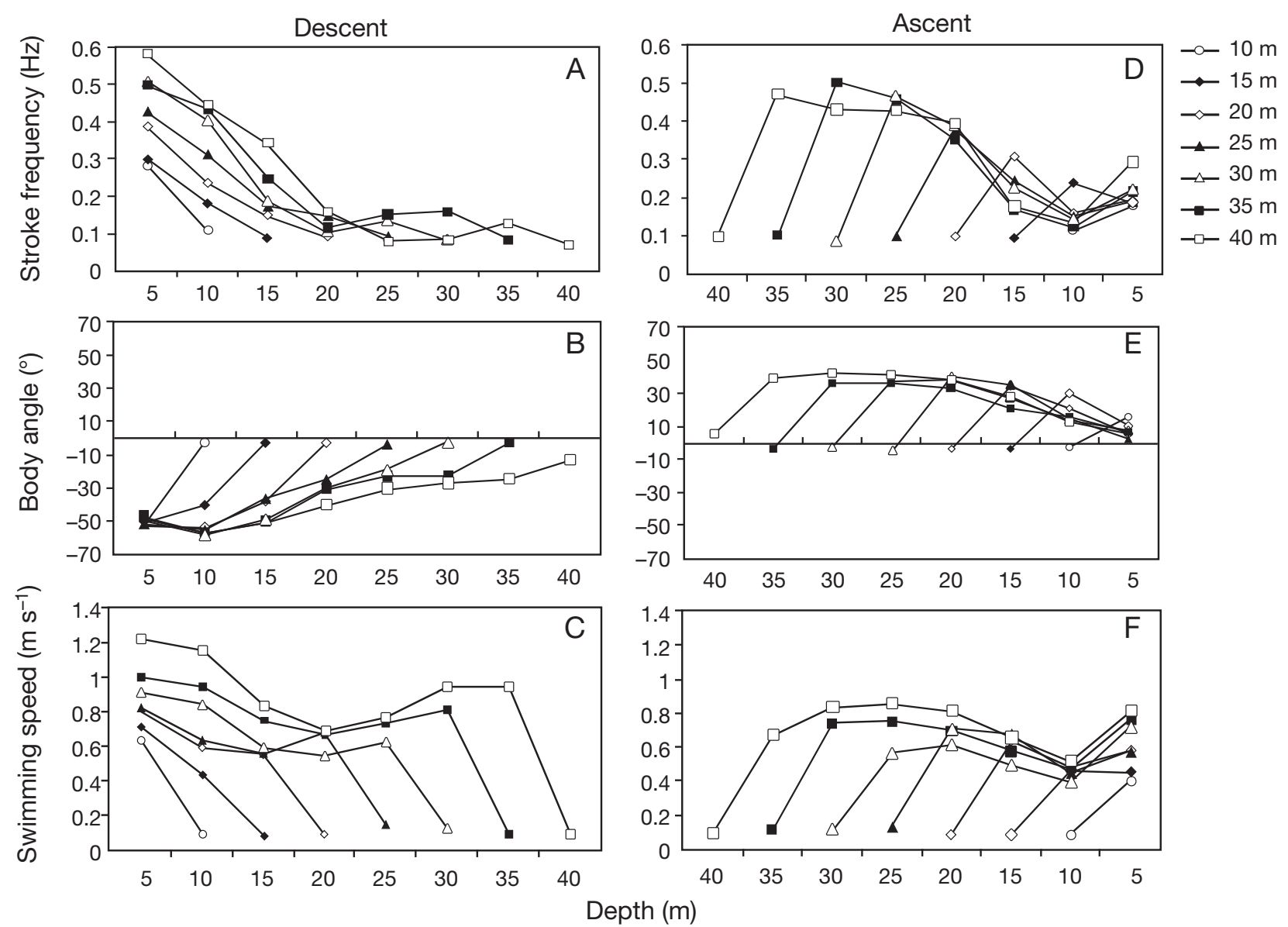

Fig. 4. Chelonia mydas. Changes in $(\mathrm{A}, \mathrm{D})$ stroke frequency, $(\mathrm{B}, \mathrm{E})$ body angle and $(\mathrm{C}, \mathrm{F})$ swimming speed with resident depth while descending and ascending. To show the general trends of the parameters, mean values are indicated over depth ranges, e.g. for 0 to 5, 5 to 10 and 10 to $15 \mathrm{~m}$, based on 331 flat-bottom dives of 4 green turtles. Shallow dives (less than $6 \mathrm{~m}, \mathrm{n}=17)$ were excluded in the analysis. Data from dives with bottom depths of each depth rank are shown separately. Different symbols indicate different maximum dive depths. Accompanying statistical analysis is shown in Table 4

Table 4. Chelonia mydas. Results of generalized linear mixed model (GLMM) with restricted maximum likelihood (REML) analysis performed during the descent and ascent phases

\begin{tabular}{|c|c|c|c|c|c|c|c|}
\hline Phase & Dependent variable & Fixed effect & No. of turtles & No. of dives & No. of records & $F$ & $\mathrm{p}$ \\
\hline \multirow[t]{9}{*}{ Descent } & \multirow[t]{3}{*}{ Stroke frequency } & Depth & 4 & 331 & 1208 & 115.403 & $<0.0001$ \\
\hline & & Bottom depth & 4 & 331 & 1208 & 66.494 & $<0.0001$ \\
\hline & & Depth $\times$ Bottom depth & 4 & 331 & 1208 & 16.995 & $<0.0001$ \\
\hline & \multirow[t]{3}{*}{ Body angle } & Depth & 4 & 331 & 1208 & 305.136 & $<0.0001$ \\
\hline & & Bottom depth & 4 & 331 & 1208 & 225.82 & $<0.0001$ \\
\hline & & Depth $\times$ Bottom depth & 4 & 331 & 1208 & 114.477 & $<0.0001$ \\
\hline & \multirow[t]{3}{*}{ Swimming speed } & Depth & 2 & 221 & 754 & 124.733 & $<0.0001$ \\
\hline & & Bottom depth & 2 & 221 & 754 & 223.402 & $<0.0001$ \\
\hline & & Depth $\times$ Bottom depth & 2 & 221 & 754 & 50.666 & $<0.0001$ \\
\hline \multirow[t]{9}{*}{ Ascent } & \multirow[t]{3}{*}{ Stroke frequency } & Depth & 4 & 331 & 1208 & 32.196 & $<0.0001$ \\
\hline & & Bottom depth & 4 & 331 & 1208 & 42.741 & $<0.0001$ \\
\hline & & Depth $\times$ Bottom depth & 4 & 331 & 1208 & 73.555 & $<0.0001$ \\
\hline & \multirow[t]{3}{*}{ Body angle } & Depth & 4 & 331 & 1208 & 65.505 & $<0.0001$ \\
\hline & & Bottom depth & 4 & 331 & 1208 & 35.807 & $<0.0001$ \\
\hline & & Depth $\times$ Bottom depth & 4 & 331 & 1208 & 158.921 & $<0.0001$ \\
\hline & \multirow[t]{3}{*}{ Swimming speed } & Depth & 2 & 221 & 754 & 446.3 & $<0.0001$ \\
\hline & & Bottom depth & 2 & 221 & 754 & 4048.683 & $<0.0001$ \\
\hline & & Depth $\times$ Bottom depth & 2 & 221 & 754 & 33.969 & $<0.0001$ \\
\hline
\end{tabular}



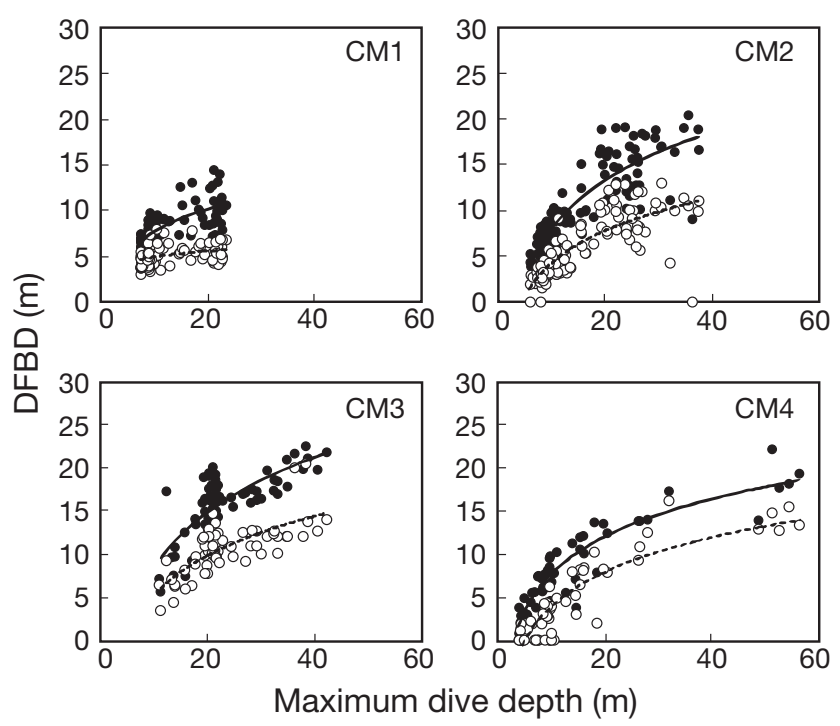

Fig. 5. Chelonia mydas. Relationships between maximum dive depth and the depth at which the flipper beat frequency was below the dominant stroke cycle frequency during the inter-nesting period (DFBD) for 4 female green turtles nested in Huyong Island, Thailand. O: ascent; •: decent; solid and dashed curves: regression curves for the descent and ascent, respectively. Accompanying statistical analysis is described in Table 3

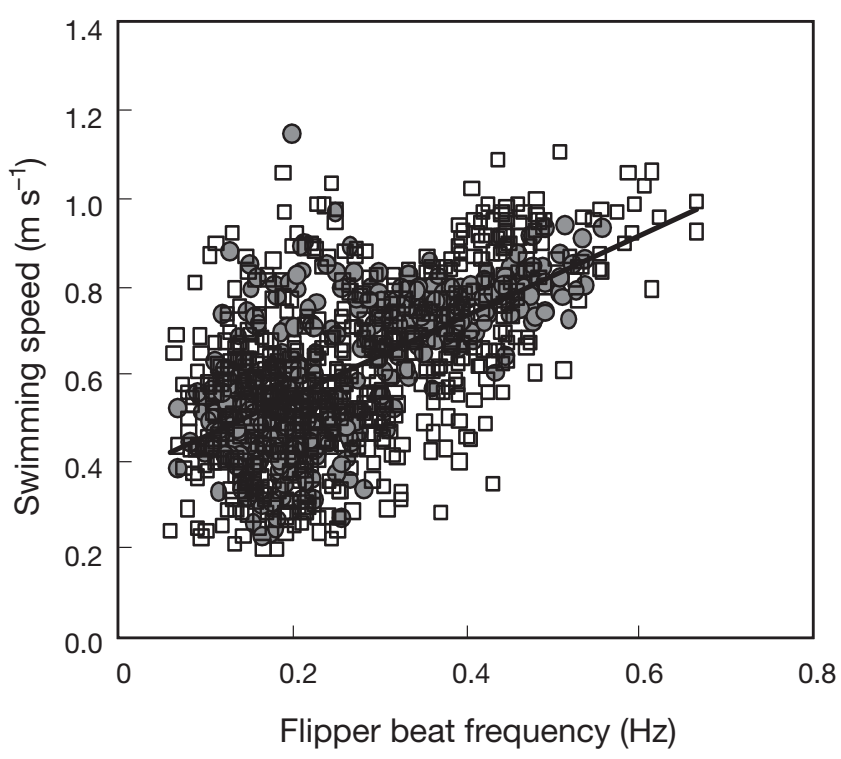

Fig. 6. Chelonia mydas. Relationships between flipper beat frequency and swimming speed for U-shaped dives during the inter-nesting period of female green turtles nested in Huyong Island, Thailand. The data on 2 individuals were pooled. Shaded circles and open squares indicate CM1 and CM2, respectively (see Table 1 ). The regression line was significant; $\mathrm{r}^{2}=0.51, F_{1,1030}=609.6812, \mathrm{p}<0.0001$, swimming speed $\left(\mathrm{m} \mathrm{s}^{-1}\right)=0.37+0.92$ flipper beat frequency $(\mathrm{Hz})$

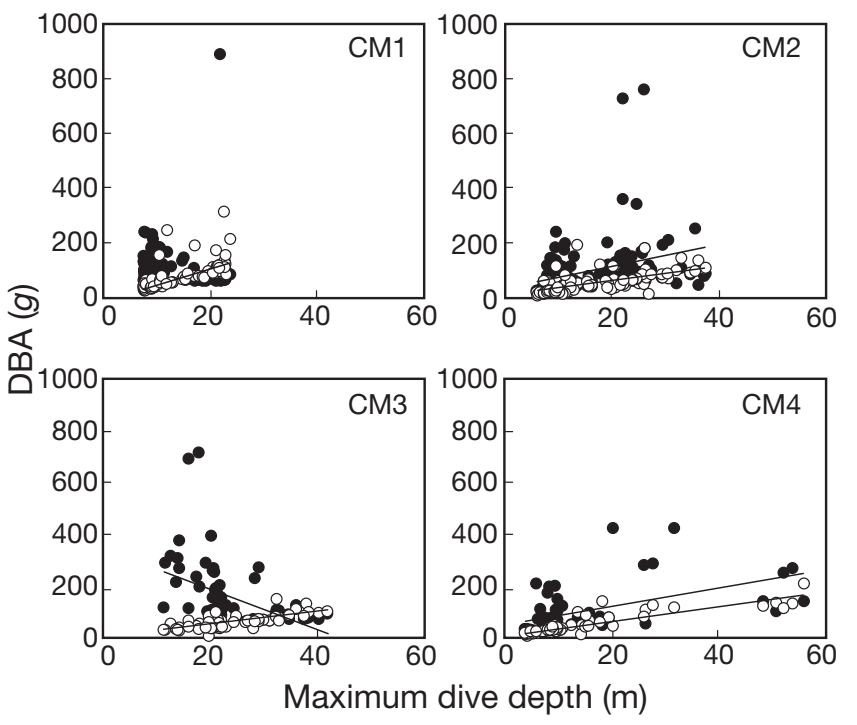

Fig. 7. Chelonia mydas. Relationships between maximum dive depth and dynamic body acceleration (DBA) during the descent phase ( $\bullet$ ) and the ascent phase (O) of U-shaped dives of 4 female green turtles. Solid lines: regression lines. Accompanying statistical analysis is described in Table 3

\section{DISCUSSION}

\section{Effect of resident depth}

An apparent, consistent pattern of flipper stroking, body angle and swimming speed in green turtles Chelonia mydas was detected with an alternation in the current depth during a dive (Fig. 3). In the initial phases of both descent and ascent, turtles performed active stroke swimming with a steep body angle. Swimming speed occurred in a zigzag pattern during the initial phases in accordance with flipper beating, suggesting that turtles might swim against buoyancy during the initial phases. Subsequently, swimming effort shifted and glide swimming was performed instead of active stroke swimming when turtles reached the DFBD. Despite less active stroking, swimming speed smoothly increased after the DFBD. This passive glide swimming of turtles indicated that residual buoyancy was exhausted and that the buoyancy then aided the swimming of the turtles. The acceleration loggers used in the present study were not attached to the flipper, but instead to the top of the carapace of turtles for simultaneous recording of both body angle and flipper beating. Therefore, the attack angle of the flippers, which may cause a reduction in thrust (e.g. Watanuki et al. 2003), was not considered in the present study and merits further examination. Regardless of the flipper angle, it was clear that the 
stroke frequency of turtles declines in parallel with changes in buoyancy with depth, similar to those of other diving animals (Williams et al. 2000, Watanuki et al. 2005, Hays et al. 2007).

\section{Evaluation of DFBD}

The maximum depth at which neutral buoyancy is attained (MDNB) is related to individual body size and weight (Minamikawa et al. 2000). Recently, Hays et al. (2004b) calculated the MDNB for green turtles at Ascension Island with approximately $120 \mathrm{~cm}$ CCL to be approximately $17 \mathrm{~m}$. In the present study, asymptotic DFBD was typically $20 \mathrm{~m}$ for descent and $12 \mathrm{~m}$ for ascent (Fig. 5). If turtles change stroke frequency based on the buoyancy at the current depth, then the DFBD during descent would be deeper than the true depth at which neutral buoyancy is attained, and vice versa. Therefore, the MDNB for the green turtles investigated is considered as the depth between 12 and $20 \mathrm{~m}$. The DFBD of the turtles studied was similar to the MDNB for green turtles at Ascension Island (Hays et al. 2004b) and may serve as an index for the depth at which turtles nearly attain neutral buoyancy.

\section{Effect of maximum dive depth}

In the present study, turtles rested on the seabed within a wide range of depths, although there seemed to be a preference in resting depth for each turtle (Table 1, Fig. 2). Maximum dive depth was found to significantly affect the swimming effort of turtles, since these organisms exerted greater effort during deeper dives (Fig. 4). These results imply that larger pre-submergence inspiration during deeper dives results in high positive or negative buoyancy and active stroking in both the descent and ascent phases (Fig. 7). However, we could not find a clear positive relationship between the maximum dive depth and DBA during the descent of some turtles (Fig. 7). The reason for this result is unknown. By observing the time-series data, we speculate that they swam at a depth near the seabed, implying that they were searching for a resting point. In contrast, the turtles went directly to the surface for breathing, and a clear relationship was found between maximum dive depth and DBA during the ascent phase. These results must be addressed by further experimental study (e.g. Wilson et al. 2006, Halsey et al. 2008, Green et al. 2009) of sea turtles.

The dive duration of green Chelonia mydas and loggerhead Caretta caretta turtles is a result of the depth obtained during the bottom phase, which may be regulated by the amount of oxygen stored in the lungs as well as by the metabolic rate (Minamikawa et al. 2000, Hochscheid et al. 2003, Hays et al. 2004b), if resting depth is not a result of active habitat selection as a consequence of lung volume, e.g. geographic condition regulates the depth selection of turtles (Seminoff et al. 2006). Therefore, our data agree with previous studies indicating that an increase in metabolic rate during the descent and ascent of deeper dives can potentially result in shorter dive durations (Figs. 2 \& 7) and suggest that selection of resting depth, in accordance with pre-submergence inspiration, plays an important role in the conservation of energy for reproduction.

\section{Body angle and swimming speed}

The body angles of turtles were steepest at the start of the descent and were related to maximum dive depth. This supports the hypothesis that turtles should initially descend at a steep angle in order to travel through the zone of highest buoyancy as efficiently as possible. However, unlike diving birds (e.g. Watanuki et al. 2005), turtles were not vertical (less than $-60^{\circ}$ ), even at the start of descent, as previously shown by Glen et al. (2001). The reason for these results is uncertain. However, shallow body angle during descent is consistent with findings for other diving animals (Le Boeuf et al. 1992, Chappell et al. 1993, Sato et al. 2003). One possibility is that body angle is restricted by the shape of the slope around the nesting site (Sato et al. 2003) or that a shallow angle allows the animals to scan for suitable foraging or resting areas (Glen et al. 2001). Body angles might be restricted due to morphological traits, since the body of hard-shelled green turtles is clearly flat and not fusiform in shape like diving animals.

There are few data available regarding direct measurements of swimming speed for adult sea turtles. Therefore, the swimming speeds of turtles were previously estimated on the basis of the results of a taggingrecapture and satellite-tracking study (see the summary by Wyneken 1997). Recently, data loggers have emerged as tools to measure aquatic animal locomotion, including swimming speed. For loggerhead turtles, which may rest mid-water and on the seabed during the inter-nesting period (Minamikawa et al. 1997, 2000), the mean swimming speed during the initial descent of mid-water resting dives is 0.27 to $0.60 \mathrm{SCL} \mathrm{s}^{-1}$ (SCL: standard carapace length in meters, $\mathrm{n}=6$ individuals; Minamikawa et al. 2000). For leatherback turtles Dermochelys coriacea, which may swim continuously and forage or attempt foraging during the inter-nesting period (Eckert et al. 1989, Eckert 2002, Myers \& Hays 2006, Fossette et al. 2008), modal speeds are 0.33 to $0.51 \mathrm{CCL} \mathrm{s}^{-1}$, with a maximum speed range 
of 1.19 to $1.65 \mathrm{CCL} \mathrm{s}^{-1}$ ( $\mathrm{n}=5$ individuals; Eckert 2002). In our initial investigation of female green turtles, which mainly rest on the seabed, the swimming speed obtained for the estimated dominant stroke frequency (i.e. 0.18 to $0.21 \mathrm{~Hz}$ ) was 0.52 to $0.60 \mathrm{CCL} \mathrm{s}^{-1}$ ( $\mathrm{n}=4$ individuals). We may need to interpret this result with caution, as carapace length may not be a good indicator of sea turtle swimming speed capacity. Nonetheless, this result suggests that sea turtles may have a distinct speed preference, which is related to organism size, even if habitat utilization differs amongst species or populations.

\section{Effect of ambient water temperature on dive duration}

While the green turtle is endothermic, it is capable of raising its body temperature through swimming activity, maintaining a body temperature slightly higher than water temperature while swimming and resting (Spotila et al. 1997). In the present study, there was no measurable importance of the effect of mean water temperature during the bottom phase of the dive (Table 3). Nesting colonies of green turtles generally occur in the tropics (Pritchard 1997). Therefore, the thermal range during dives may be narrow, since female green turtles are shallow divers during the inter-nesting period (Hochscheid et al. 1999, Hays et al. 2000). In contrast, over a wide range of temperatures, dive duration has been shown to vary robustly with water temperature in loggerhead turtles with, for example, dive durations of $>6 \mathrm{~h}$ during the cold midwinter temperatures encountered at high latitudes (Hochscheid et al. 2005).

\section{Diel changes at resting depth}

The present study indicates that depth selection during a dive affects the performance of resting (Figs. 2 \& 4). Previous studies suggested that green and loggerhead turtles seem to select resting depth within a range in which the lungs can be utilized to achieve close to neutral buoyancy (Minamikawa et al. 2000, Hays et al. 2004b). Since the range of asymptotic DFBDs was about 12 to $20 \mathrm{~m}$ in the present study (Fig. 5), turtles resting at this depth range do so efficiently. In the present study, mean resting depths ranged from $9.23 \pm 2.09$ to $13.29 \pm 6.62 \mathrm{~m}$ for night dives and from $16.43 \pm 20.16$ to $26.31 \pm 7.91 \mathrm{~m}$ for daytime dives (Table 2). Therefore, the gravid female turtles investigated in our study seemed to be resting around the depth near the range of asymptotic DFBDs, and deep dives that exceeded the upper threshold of the depth range were rare. However, there was an apparent alternation in dive depth between daytime and nighttime, as daytime dives and resident depth were deeper than those observed during the night (Fig. 1, Table 1).

A previous satellite-tracking study and home range analysis suggested that horizontal utilization by female green turtles was within a $7 \mathrm{~km}$ buffer area around Huyong Island (Yasuda 2007). The diel alternation in the observed resting depth might indicate a reproductive strategy for females. One possibility is a beneficial change in vertical space to obtain refuge from energyconsuming encounters with males (Lee \& Hays 2004, Schofield et al. 2006) or predators (e.g. large sharks; Fergusson et al. 2000, Hays et al. 2001). In fact, females commonly suffer from the superfluous mating and copulation that arises from male coercion in nature (Lee \& Hays 2004). These behaviours are likely to be observed in daytime (Booth \& Peters 1972, Schofield et al. 2006). In addition, Hays et al. $(1991,1999)$ found that there was a systematic change in diel patterns in diving behaviour between the start and end of an interval, suggesting that turtles may not be simply employing an energy conservation strategy. Recording of the behaviour during the overall inter-nesting interval and an intensive analysis, including other diving patterns, are needed to achieve a better understanding of female reproductive strategies.

Acknowledgements. We thank K. Kittiwattanawong, W. Klomin, J. Hatayama, T. Noda, and all the members of the sea turtle research group in the Royal Thai Navy for their assistance with field surveys. We also thank $H$. Mitamura and 4 anonymous reviewers for their comments on this manuscript. The present study was conducted with the permission of the National Research Council in Thailand and was partly supported by a Research Fellowship for Young Scientists of JSPS to T.Y. (No. 19.5206) and Kyoto University Global COE Program: Informatics Education and Research Center for KnowledgeCirculation Society.

\section{LITERATURE CITED}

Booth J, Peters JA (1972) Behavioural studies on the green turtle (Chelonia mydas) in the sea. Anim Behav 20:808-812

Boyd IL, Reid K, Bevan RM (1995) Swimming speed and allocation of time during the dive cycle in Antarctic fur seals. Anim Behav 50:769-784

> Butler PJ, Jones DR (1997) Physiology of diving birds and mammals. Physiol Rev 77:837-899

> Chappell MA, Shoemaker VH, Janes DN, Bucher TL (1993) Diving behaviour during foraging in breeding Adélie penguins. Ecology 74:1204-1215

Eckert SA (2002) Swim speed and movement patterns of gravid leatherback sea turtles (Dermochelys coriacea) at St Croix, US Virgin Islands. J Exp Biol 205:3689-3697

Eckert SA, Eckert KL, Ponganis P, Kooyman GL (1989) Diving and foraging behaviour of leatherback sea turtles (Dermochelys coriacea). Can J Zool 67:2834-2840 
Fergusson IK, Compagno LJV, Marks MA (2000) Predation by white sharks Carcharodon carcharias (Chondrichthyes: Lamnidae) upon chelonians, with new records from the Mediterranean Sea and a first record of the ocean sunfish Mola mola (Osteichthyes: Molidae) as stomach contents. Environ Biol Fishes 58:447-453

Fossette S, Gaspar P, Handrich Y, Le Maho Y, Georges JY (2008) Dive and beak movement patterns in leatherback turtles Dermochelys coriacea during internesting intervals in French Guiana. J Anim Ecol 77:236-246

Glen F, Broderick AC, Godley BJ, Metcalfe JD, Hays GC (2001) Body angles for green turtles (Chelonia mydas). J Mar Biol Assoc UK 81:683-686

> Green JA, Halsey LG, Wilson RP, Frappell PB (2009) Estimating energy expenditure of animals using the accelerometry technique: activity, inactivity and comparison with the heart-rate technique. J Exp Biol 212:471-482

Halsey LG, Shepard ELC, Hulston CJ, Venables MC, White CR, Jeukendrup AE, Wilson RP (2008) Acceleration versus heart rate for estimating energy expenditure and speed during locomotion in animals: tests with an easy model species, Homo sapiens. Zoology 111:231-241

$>$ Hays GC (2008) Sea turtles: a review of some key recent discoveries and remaining questions. J Exp Mar Biol Ecol 356:1-7

Hays GC, Webb PI, Hayes JP, Priede IG, French J (1991) Satellite tracking of a loggerhead turtle (Caretta caretta) in the Mediterranean. J Mar Biol Assoc UK 71:743-746

Hays GC, Luschi P, Papi F, del Seppia C, Marsh R (1999) Changes in behaviour during the internesting period and postnesting migration for Ascension Island green turtles. Mar Ecol Prog Ser 189:263-273

- Hays GC, Adams CR, Broderick AC, Godley BJ, Lucas DJ, Metcalfe JD, Prior AA (2000) The diving behaviour of green turtles at Ascension Island. Anim Behav 59:577-586

Hays GC, Åkesson S, Broderick AC, Glen F and others (2001) The diving behaviour of green turtles undertaking oceanic migration to and from Ascension Island: dive durations, dive profiles and depth distribution. J Exp Biol 204:4093-4098

> Hays GC, Broderick AC, Glen F, Godley BJ (2002) Change in body mass associated with long-term fasting in a marine reptile: the case of green turtles (Chelonia mydas) at Ascension Island. Can J Zool 80:1299-1302

> Hays GC, Metcalfe JD, Walne AW, Wilson RP (2004a) First records of flipper beat frequency during sea turtle diving. J Exp Mar Biol Ecol 303:243-260

> Hays GC, Metcalfe JD, Walne AW (2004b) The implications of lung-regulated buoyancy control for dive depth and duration. Ecology 85:1137-1145

Hays GC, Marshall GJ, Seminoff JA (2007) Flipper beat frequency and amplitude changes in diving green turtles, Chelonia mydas. Mar Biol 150:1003-1009

Hochscheid S, Godley BJ, Broderick AC, Wilson RP (1999) Reptilian diving: highly variable dive patterns in the green turtle Chelonia mydas. Mar Ecol Prog Ser 185:101-112

> Hochscheid S, Bentivegna F, Speakman JR (2003) The dual function of the lung in chelonian sea turtles: buoyancy control and oxygen storage. J Exp Mar Biol Ecol 297: 123-140

> Hochscheid S, Bentivegna F, Hays GC (2005) First records of dive durations for a hibernating sea turtle. Biol Lett 1: $82-86$

> Houghton JDR, Broderick AC, Godley BJ, Metcalfe JD, Hays GC (2002) Diving behaviour during the internesting interval for loggerhead turtles Caretta caretta nesting in Cyprus. Mar Ecol Prog Ser 227:63-70
Houghton JDR, Cedras A, Myers AE, Liebsch N, Metcalfe JD, Mortimer JA, Hays GC (2008) Measuring the state of consciousness in a free-living diving sea turtle. J Exp Mar Biol Ecol 356:115-120

> Le Boeuf BJ, Naito Y, Asaga T, Crocker D (1992) Swimming speed in a northern elephant seal: metabolic and foraging implications. Can J Zool 70:786-795

Lee PLM, Hays GC (2004) Polyandry in marine turtles: females make the best of a bad job. Proc Natl Acad Sci USA 101:6530-6535

> Limpus CJ, Reed PC (1985) The loggerhead turtle, Caretta caretta, in Queensland: observations on interesting behavior. Aust Wildl Res 12:535-540

Lovvorn JR, Croll DA, Liggins GA (1999) Mechanical versus physiological determinants of swimming speeds in diving Brünnich's guillemots. J Exp Biol 202:1741-1752

Marshall GJ (1998) CRITTERCAM: an animal-borne imaging and data logging system. Mar Technol Soc J 32:11-17

Minamikawa S, Naito Y, Uchida I (1997) Buoyancy control in diving behavior of the loggerhead turtle, Caretta caretta. J Ethol 15:109-118

- Minamikawa S, Naito Y, Sato K, Matsuzawa Y, Bando T, Sakamoto W (2000) Maintenance of neutral buoyancy by depth selection in the loggerhead turtle Caretta caretta. J Exp Biol 203:2967-2975

Myers AE, Hays GC (2006) Do leatherback turtles Dermochelys coriacea forage during the breeding season? A combination of data-logging devices provide new insights. Mar Ecol Prog Ser 322:259-267

Pritchard PCH (1997) Evolution, phylogeny, and current status. In: Lutz PL, Musick JA (eds) The biology of sea turtles. CRC Press, Boca Raton, FL, p 1-28

Sato K, Mitani Y, Cameron MF, Siniff DB, Naito Y (2003) Factors affecting stroking patterns and body angle in diving Weddell seals under natural conditions. J Exp Biol 206: 1461-1470

Schall R (1991) Estimation in generalized liner models with random effects. Biometrika 78:719-727

Schmidt-Nielsen K (1984) Scaling: Why is animal size so important? Cambridge University Press, Cambridge

Schofield G, Katselidis KA, Dimopoulos P, Pantis JD, Hays GC (2006) Behaviour analysis of the loggerhead sea turtle Caretta caretta from direct in-water observation. Endang Species Res 2:71-79

Seminoff JA, Jones TT, Marshall GJ (2006) Underwater behaviour of green turtles monitored with video-timedepth recorders: What's missing from dive profiles? Mar Ecol Prog Ser 322:269-280

Spotila JR, O'Connor MP, Paladino FV (1997) Thermal biology. In: Lutz PL, Musick JA (eds) The biology of sea turtles. CRC Press, Boca Raton, FL, p 297-314

Starbird CH, Hills-Starr Z, Harvey JT, Eckert SA (1999) Internesting movements and behavior of hawksbill turtles (Eretmochelys imbricate) around Buck Island Reef National Monument, St. Croix, U.S. Virgin Island. Chelonian Conserv Biol 3:237-243

Tsuda Y, Kawabe R, Tanaka H, Mitsunaga Y, Hiraishi T, Yamamoto K, Nashimoto K (2006) Monitoring the spawning behaviour of chum salmon with an acceleration data logger. Ecol Freshw Fish 15:264-274

> Watanabe S, Izawa M, Kato A, Ropert-Coudert Y, Naito Y (2005) A new technique for monitoring the detailed behaviour of terrestrial animals: a case study with the domestic cat. Appl Anim Behav Sci 94:117-131

Watanuki Y, Niizuma Y, Gabrielsen GW, Sato K, Naito Y (2003) Stroke and glide of wing-propelled dives: deep diving seabirds adjust surge frequency to buoyancy change 
with depth. Proc R Soc Lond B Biol Sci 270:483-488

Watanuki Y, Takahashi A, Daunt F, Wanless S, Harris M, Sato K, Naito Y (2005) Regulation of stroke and glide in a footpropelled avian diver. J Exp Biol 208:2207-2216

Williams TM, Friedl WA, Haun JE, Chun NK (1993) Balancing power and speed in bottlenose dolphin (Tursiops truncates). Symp Zool Soc Lond 66:383-394

Williams TM, Davis RW, Fuiman LA, Francis J and others (2000) Sink or swim: strategies for cost-efficient diving by marine mammals. Science 288:133-136

Wilson RP, Hustler K, Ryan PG, Burger AE, Noldeke EC (1992) Diving birds in cold water: Do Archimedes and Boyle determine energetic costs? Am Nat 140:179-200

Wilson RP, White CR, Quintana F, Halsey LG, Liebsch N, Martin GR, Butler PJ (2006) Moving towards acceleration for estimates of activity-specific metabolic rate in free-living

Editorial responsibility: Rory Wilson,

Swansea, UK animals: the case of the cormorant. J Anim Ecol 75: 1081-1090

Wyneken J (1997) Sea turtle locomotion: Mechanics, behavior and energetics. In: Lutz PL, Musick JA (eds) The biology of sea turtles. CRC Press, Boca Raton, FL, p 165-198

Yasuda T (2007) Analytical study on acquisition of ecological information on marine animals for evaluation of a marine protected area. PhD dissertation, Kyoto University, Kyoto

Yasuda $\mathrm{T}$, Tanaka H, Kittiwattanawong $\mathrm{K}$, Mitamura $\mathrm{H}$, Klom-In W, Arai N (2006) Do female green turtles (Chelonia mydas) exhibit reproductive seasonality in a yearround nesting rookery? J Zool (Lond) 269:451-457

Yoda K, Naito Y, Sato K, Takahashi A and others (2001) A new technique for monitoring the behaviour of free-ranging Adelie penguins. J Exp Biol 204:685-690

Submitted: January 8, 2009; Accepted: April 24, 2009 Proofs received from author(s): June 23, 2009 